JKM (Jurnal Kebidanan Malahayati),Vol 7,No.3.Juli 2021,

ISSN (Print) 2476-8944 ISSN (Online) 2579-762X, Hal 533-543

\title{
PENDEKATAN PARTISIPATIF DALAM PENINGKATAN PEMAHAMAN IBU MENGENAI NEONATUS RISIKO TINGGI
}

\author{
Holidah ${ }^{1}$, Fenita Purnama Sari Indah²* \\ Dosen STIKes Widya Dharma Husada Tangerang \\ *Korespondensi fenita.purnama@masda.ac.id
}

\section{ABSTRACT PARTICIPATORY APPROACHES TO IMPROVING MOTHER'S UNDERSTANDING OF HIGH- RISK NEONATES}

Background: The total infant mortality rate (IMR) in Indonesia shows that the infant mortality rate in Indonesia is still relatively high when compared to ASEAN member countries, which is 4.6 times higher than Malaysia, 1.3 times more.

Purpose: Analyzing the causative factors and indications for high-risk events and to analyze the increased understanding of mothers about high-risk neonates.

Methods: The research was conducted in 2 stages, with quantitative research methods. In the first phase, a survey was conducted of 100 mothers who have babies and toddlers in the Pamulang Puskesmas working area. In the second phase of research, with a participatory approach, namely the provision of health education about High Risk neonates. The research design was a quasi experiment with non-equivalent control group design with pre test and post test design. A total of 27 samples were taken using purposive sampling technique. The data were processed using the Willcoxon test.

Results: In this study, the results obtained were $p$ value $0.011 \quad(<0.05)$, which means that there is a difference in understanding between the pretest and posttest, there has been an increase in the average value of respondents' knowledge about high-risk neonates after health education. The mean value of maternal knowledge increased from 25.8 when the pre-test was conducted to 27.4 at the post-test.

Conclusion: There are changes when after health education is carried out, the community can understand well the material provided

Suggestion: health institution to increase understanding of pregnant women and mothers who have babies and toddlers in a more innovative and participatory way about the factors that cause high risk neonates and indications of high risk neonates in mothers. For the community, it can increase knowledge and insight as a reference in order to prevent the occurrence of high risk neonates in pregnant women and mothers who have babies and toddlers.

Keywords: Participatory Approaches, High-Risk Neonates, Mother's Understanding

\section{ABSTRAK}

Latar Belakang: Jumlah Angka Kematian Bayi (AKB) di Indonesia menunjukan bahwa tingkat kematian bayi di Indonesia masih tergolong tinggi jika dibandingkan dengan negara-negara anggota ASEAN, yaitu 4,6 kali lebih tinggi dari Malaysia, 1,3 kali lebih.

Tujuan: Penelitian bertujuan untuk menganalisis faktor penyebab serta indikasi kejadian berisiko tinggi serta menganalisis peningkatan pemahaman ibu mengenai neonatus berisiko tinggi.

Metode: Penelitian dilakukan dengan 2 tahap, dengan metode penelitian kuantitatif. Pada tahap pertama dilakukan survey terhadap ibu yang memiliki bayi dan balita di wilayah kerja Puskesmas Pamulang, berjumlah 100 ibu. Pada penelitian tahap kedua, dengan pendekatan partisipatif yaitu pemberian pendidikan kesehatan mengenai neonatus Risiko Tinggi. Rancangan penelitian adalah quasi experiment dengan desain Non-equivalent Control Group Design with pre test dan post test design. Sampel diambil sebanyak 27 sampel dengan menggunakan teknik purposive sampling data diolah menggunakan Uji Willcoxon.

Hasil: Pada penelitian ini diperoleh hasil bahwa diperoleh $p$ value $0,011(<0,05)$ yang berarti bahwa terdapat perbedaan pemahaman antara pretest dan posttest, telah terjadi peningkatan nilai rata-rata pengetahuan responden mengenai neonatal risiko tinggi setelah dilakukan pendidikan kesehatan. Nilai rata-rata pengetahuan ibu mengalami kenaikan dari 25,8 saat pre-test dilakukan menjadi 27,4 saat post-test.

Kesimpulan:Terdapat perubahan pada saat setelah dilakukan pendidikan kesehatan, masyarakat dapat memahami dengan baik dari materi yang diberikan. 


\section{Holidah, Fenita Purnama Sari Indah}

Saran : bagi instansi kesehatan agar dapat meningkatkan pemahaman ibu hamil serta ibu yang memiliki bayi dan balita dengan cara yang lebih inovatif dan partisipatif tentang faktor penyebab kejadian neonatus risiko tinggi maupun indikasi kejadian neonatus risiko tinggi pada ibu. Bagi Masyarakat dapat meningkatkan pengetahuan dan wawasan sebagai acuan agar dapat mencegah terjadinya kejadian neonatus risiko tinggi pada ibu hamil serta ibu yang memiliki bayi dan balita.

Kata Kunci : Pendekatan Partisipatif, Pemahaman Ibu, Neonatus Risiko Tinggi

\section{PENDAHULUAN}

Kesehatan merupakan salah satu dari hak asasi manusia, seperti termasuk dalam UUD 1945. Dalam UUD 1945 juga dinyatakan bahwa setiap orang berhak hidup sejahtera lahir dan batin, bertempat tinggal dan mendapatkan lingkungan hidup yang baik dan sehat serta berhak memperoleh pelayanan kesehatan (Hidayat, 2017) (Arliman, 2018). Kesehatan sebagai hak asasi manusia, mengandung suatu kewajiban untuk menyehatkan yang sakit dan berupaya mempertahankan yang sehat untuk tetap sehat. Kesehatan adalah keadaan sejahtera dari badan, jiwa dan sosial yang memungkinan setiap orang hidup produktif secara sosial dan ekonomis. Hal ini melandasi pemikiran bahwa sehat adalah investasi (Alim, dkk, 2020).

Kesehatan juga merupakan salah satu indikator penting dalam menentukan kesejahteraan suatu bangsa di samping ekonomi dan sosial. Hal ini ditegaskan dalam Undang-Undang Dasar tahun 1945 pasal $28 \mathrm{H}$ ayat 1 , yang menyatakan bahwa setiap orang berhak memperoleh pelayanan kesehatan. Selain itu Undang-Undang No 36 Tahun 2009 tentang kesehatan juga menjelaskan dengan tegas tentang hak dan kewajiban pemerintah maupun masyarakat yang berkenaan dengan pemenuhan akan kesehatan (Perwira, 2014). Ibu dan Anak (KIA) masih menjadi masalah kesehatan di Indonesia. Hal ini dikarenakan angka kematian ibu dan angka kematian bayi yang ada di Indonesia yang masih tinggi. Hingga saat ini sudah banyak program-program pembangunan kesehatan di Indonesia yang ditujukan pada penanggulangan masalah-masalah kesehatan ibu dan anak. Pada dasarnya program-program tersebut lebih menitikberatkan pada upaya-upaya penurunan angka kematian bayi dan anak, angka kelahiran kasar dan angka kematian ibu (Saputra, dkk, 2013) (Pinontoan \& Tombokan 2015).

Masalah kematian maupun kesakitan pada ibu dan anak sesungguhnya tidak terlepas dari faktor-faktor sosial budaya dan lingkungan di dalam masyarakat dimana mereka berada. Disadari atau tidak, faktor-faktor kepercayaan dan pengetahuan budaya seperti konsepsi-konsepsi mengenai berbagai pantangan, hubungan sebab-akibat antara makanan dan kondisi sehat-sakit, kebiasaan dan ketidak tahuan, sering kali membawa dampak baik positif maupun negatif terhadap kesehatan ibu dan anak. Pola makan, misalnya, pada dasarnya adalah merupakan salah satu selera manusia dimana peran kebudayaan cukup besar. Hal ini terlihat bahwa setiap daerah mempunyai pola makan tertentu, termasuk pola makan ibu hamil dan anak yang disertai dengan kepercayaan akan pantangan, tabu, dan anjuran terhadap beberapa makanan tertentu (Ummah, 2018) (Khasanah, 2013).

Angka kematian bayi adalah jumlah yang meninggal sebelum mencapai usia 1 (satu) tahun dari 1000 kelahiran hidup penduduk pada tahun yang sama. Angka Kematian Bayi (AKB) di dunia masih tergolong tinggi. Berdasarkan data UNICEF, angka kematian bayi di dunia mencapai lebih 10 juta kematian. Dari 10 juta kematian bayi, hampir 90 $\%$ kematian bayi terjadi di negara-negara berkembang (Wahyuni, 2020) (Nurhafni dkk, 2021). Indonesia merupakan Negara yang memiliki jumlah kematian bayi relatif tinggi bila dibandingkan dengan negara ASEAN lain (Sary \& Latra 2013) (Prahutama, dkk, 2017). Angka kematian bayi merupakan indikator yang penting untuk mencerminkan keadaan derajat kesehatan di suatu masyarakat, karena bayi yang baru lahir sangat sensitif terhadap keadaan lingkungan tempat orang tua si bayi tinggal dan sangat erat kaitannya dengan status sosial orang tua si bayi. Dengan demikian angka kematian bayi merupakan tolok ukur yang sensitif dari semua upaya intervensi yang dilakukan oleh pemerintah khususnya di bidang kesehatan. Angka Kematian Bayi adalah Angka yang menunjukkan banyaknya kematian bayi usia 0 tahun dari setiap 1000 kelahiran hidup pada tahun tertentu atau dapat dikatakan juga sebagai probabilitas bayi meninggal sebelum mencapai usia satu tahun (dinyatakan dengan per seribu kelahiran hidup) (Rahmawati, dkk, 2016) (Dwiargatra \& Purhadi, 2020) (Liufeto \& Angi, 2019).

Data yang ada di Dinkes Kota Tangerang Selatan, tahun 2012 untuk Angka Kematian Ibu (AKB) terdapat 46 kasus, tahun 2013 terdapat 21 kasus AKB serta tahun 2014 ada penurunan mulai 
JKM (Jurnal Kebidanan Malahayati),Vol 7,No.3.Juli 2021,

ISSN (Print) 2476-8944 ISSN (Online) 2579-762X, Hal 533-543

Januari hingga akhir Oktober tercatat ada 10 kasus AKB (Maghfiroh, 2015). Pada Kecamatan Pamulang, berdasarkan data sekunder yang diperoleh dari monitoring capaian kinerja program UKM UPT Puskesmas Pamulang, pada data kumulatif tercatat ada 50 kasus kematian bayi. Pada tahun 2018, seperti terlihat pada tabel 1 telah terjadi kematian bayi di Kelurahan Pamulang Barat sebanyak 5 kasus kematian bayi. Sebagian besar kematian anak di Indonesia saat ini terjadi pada masa baru lahir (neonatal), bulan pertama kehidupan. Kemungkinan anak meninggal pada usia yang berbeda adalah 19 per seribu selama masa neonatal, 15 per seribu dari usia 2 hingga 11 bulan dan 10 per seribu dari usia satu sampai lima tahun. Penyebab kematian bayi terbanyak yaitu BBLR 38,94\%, asfiksia lahir 27,97\%. Hal ini menunjukkan bahwa 66,91\% kematian prenatal dipengaruhi oleh kondisi ibu saat melahirkan. Gangguan sirkulasi tali pusat dicurigai menyebabkan 20\% kematian janin, dimana gangguan mekanis dari tali pusat dapat berupa lilitan tali pusat dan prolaps tali pusat atau mungkin timbul dari anatomi tali pusat yang abnormal seperti tali pusat yang tersimpul (true knot), koil abnormal (hypocoiling dan hypercoiling), panjang tali pusat dan insersi tali pusat yang abnormal. Gangguan aliran tali pusat $50 \%$ secara signifikan menyebabkan asfiksia pada janin, yang menimbulkan efek terhadap organ dan metabolisme janin baik akut maupun kronis, sehingga pada akhirnya akan mempengaruhi perkembangan bayi yang dapat mempengaruhi luaran bayi lahir (UPT Puskesmas Pamulang, 2018).

Tabel 1.

Monitoring Capaian Kinerja Program UKM UPT Puskesmas Pamulang

\begin{tabular}{clccc}
\hline Program & \multicolumn{1}{c}{ Kegiatan } & $\begin{array}{c}\text { Target 1 } \\
\text { tahun }\end{array}$ & $\begin{array}{c}\text { Kumulatif } \\
\text { s.d. } \\
\text { Desember }\end{array}$ & $\%$ \\
\hline \multirow{2}{*}{$\begin{array}{l}\text { Angka kematian bayi } \\
\text { Cakupan pelayanan }\end{array}$} & 0 & 5 & \\
ANAK & $\begin{array}{l}\text { Neonatal risiko tinggi } \\
\text { Cakupan pelayanan }\end{array}$ & 279 & 133 & 56,05 \\
& $\begin{array}{l}\text { neonatal pertama KN1 } \\
\text { Cakupan kunjungan bayi }\end{array}$ & 1949 & 1969 & 101 \\
& lengkap & 1857 & 1868 & 100,30 \\
\hline
\end{tabular}

Sumber : UPT Puskesmas Pamulang

Salah satu faktor yang diketahui terkait dengan kematian neonatal dan morbiditas dan telah memberikan kontribusi untuk berbagai hasil kesehatan yang buruk bagi bayi serta anak dan akan berdampak jangka panjang terhadap gizi dan kehidupan selanjutnya adalah Berat badan lahir rendah (BBLR). Berdasarkan latar belakang tersebut, maka penelitian ini bertujuan untuk menganalisis peningkatan pemahaman ibu mengenai neonatus berisiko tinggi.

\section{METODOLOGI PENELITIAN}

Penelitian ini merupakan penelitian kuantitatif, dengan desain cross sectional. Langkahlangkah penelitian ini dilakukan dengan 2 tahap. Pada tahap pertama dilakukan survey terhadap ibu yang memiliki bayi dan balita di wilayah kerja Puskesmas Pamulang. Wilayah Kerja Puskesmas Pamulang mencakup Kecamatan Pamulang, terdiri dari Kelurahan Pamulang Barat dan Pamulang Timur. Survey ini dilakukan untuk menganalisis faktor penyebab ibu melahirkan bayi neonatus
Risiko Tinggi serta mengetahui jumlah bayi yang terindikasi dilahirkan dengan keadaan risiko tinggi. Jumlah sampel pada survey ini yaitu 100 ibu yang memiliki bayi dan balita di wilayah kerja Puskesmas Pamulang.

Pada penelitian tahap kedua, penelitian juga bersifat kuantitatif dengan menggunakan metode pendekatan partisipatif yaitu pemberian pendidikan kesehatan mengenai neonatus Risiko Tinggi. Rancangan penelitian adalah quasi experiment dengan desain Non-equivalent Control Group Design with pre test dan post test design. Sampel diambil sebanyak 27 sampel dengan menggunakan teknik purposive sampling. Instrumen digunakan kuesioner pretest dan posttest. Analisis data dilakukan secara univariat dan bivariat menggunakan Uji Willcoxon untuk mengetahui pengaruh pendidikan kesehatan kesehatan melalui pendekatan partisipatif. Pemilihan Uji Willcoxon dilakukan sebab data tidak berdistribusi normal. 


\section{HASIL DAN PEMBAHASAN}

Hasil yang diperoleh pada penelitian ini terbagi menjadi 2 (dua). Pada penelitian pertama dilakukan survey terhadap 100 ibu yang memiliki bayi dan balita di Wilayah Kerja Puskesmas Pamulang mengenai karakteristik responden, faktor penyebab, serta indikasi kejadian neonatus Risiko Tinggi pada bayi yang dilahirkan responden. Adapun hasil penelitian ini yaitu:

\section{Karakteristik Responden Jenis pekerjaan}

Tabel 2.

Distribusi Frekuensi Jenis Pekerjaan Responden

\begin{tabular}{lcc}
\hline $\begin{array}{c}\text { Pekerjaan } \\
\text { Responden }\end{array}$ & Frekuensi & $\begin{array}{c}\text { Persentase } \\
(\%)\end{array}$ \\
\hline IRT & 79 & 79 \\
Buruh & 1 & 1 \\
Karyawan & 12 & 12 \\
Wiraswasta & 5 & 5 \\
PNS & 3 & 3 \\
\hline \multicolumn{1}{r}{ Total } & 100,0 & 100,0 \\
\hline
\end{tabular}

Distribusi frekuensi karakteristik responden dapat dilihat pada tabel 2, berdasarkan jenis pekerjaan, terlihat bahwa sebagian besar responden adalah IRT (Ibu Rumah Tangga) sebesar $79 \%$.

\section{Tingkat pendidikan ibu}

Tabel 3.

Distribusi Frekuensi Tingkat Pendidikan Responden

\begin{tabular}{|c|c|c|}
\hline $\begin{array}{l}\text { Tingkat Pendidikan } \\
\text { Responden }\end{array}$ & Frekuensi & $\begin{array}{c}\text { Persentase } \\
(\%)\end{array}$ \\
\hline SD & 11 & 11 \\
\hline SMP & 12 & 12 \\
\hline SMA & 50 & 50 \\
\hline D3/S1 & 27 & 27 \\
\hline Total & 100,0 & 100,0 \\
\hline
\end{tabular}

Distribusi frekuensi karakteristik responden dapat dilihat pada tabel 3 , berdasarkan tingkat pendidikan, sebagian besar responden berpendidikan SMA sebesar $50 \%$.

\section{Faktor Penyebab Kejadian Neonatus Risiko Tinggi \\ Paritas Responden \\ Paritas menunjukkan jumlah anak yang pernah dilahirkan oleh seorang wanita. Pada tabel 4}

menunjukkan distribusi frekuensi faktor penyebab kejadian neonatus Risiko Tinggi berdasarkan paritas, terlihat bahwa hampir setengah responden memiliki paritas yang berisiko (49\%).

Tabel 4.

Distribusi Frekuensi Faktor Paritas Responden

\begin{tabular}{ccc}
\hline Paritas & Frekuensi & $\begin{array}{c}\text { Persentase } \\
(\%)\end{array}$ \\
\hline Beresiko & 49 & 49 \\
Tidak Beresiko & 51 & 51 \\
\hline Total & 100,0 & 100,0 \\
\hline
\end{tabular}

Usia Responden

Tabel 5.

Distribusi Frekuensi Faktor Usia Responden

\begin{tabular}{lcc}
\hline \multicolumn{1}{c}{ Usia } & Frekuensi & $\begin{array}{c}\text { Persentase } \\
(\%)\end{array}$ \\
\hline $\begin{array}{l}\text { Beresiko } \\
(<20 \text { tahun dan }>35\end{array}$ & 18 & 18 \\
tahun) & & \\
$\begin{array}{l}\text { Tidak Beresiko } \\
(20-35 \text { tahun })\end{array}$ & 82 & 82 \\
\hline \multicolumn{1}{c}{ Total } & 100,0 & 100,0 \\
\hline
\end{tabular}

Umur ibu saat hamil Usia ibu yang berisiko untuk terjadinya kematian maternal adalah usia kurang dari 20 tahun atau lebih dari 35 tahun.lbu yang hamil pada usia $<20$ tahun atau $>35$ tahun memiliki risiko untuk mengalami kematian maternal 3,4 kali lebih besar daripada ibu yang berusia 20 35 tahun (Fibriana,2007). Pada tabel 5 menunjukkan distribusi frekuensi faktor penyebab kejadian neonatus Risiko Tinggi berdasarkan usia responden, sebanyak $18 \%$ responden memiliki usia berisiko ( $<20$ tahun dan $>35$ tahun).

\section{Kejadian Anemia}

Tabel 6.

Distribusi Frekuensi Faktor Kejadian Anemia

\begin{tabular}{lcc}
\hline Kejadian Anemia & Frekuensi & $\begin{array}{c}\text { Persentase } \\
(\%)\end{array}$ \\
\hline Ya & 20 & 20 \\
Tidak & 80 & 80 \\
\hline \multicolumn{1}{c}{ Total } & 100,0 & 100,0 \\
\hline
\end{tabular}

Pada tabel 6 menunjukkan distribusi frekuensi faktor penyebab kejadian neonatus Risiko Tinggi berdasarkan faktor kejadian anemia, sebanyak $20 \%$ responden mengalami kejadian anemia saat kehamilan. 
JKM (Jurnal Kebidanan Malahayati),Vol 7,No.3.Juli 2021,

ISSN (Print) 2476-8944 ISSN (Online) 2579-762X, Hal 533-543

Preeklampsia

Tabel 7.

Distribusi Frekuensi Faktor Preeklampsia

\begin{tabular}{lcc}
\hline Preeklampsia & Frekuensi & $\begin{array}{c}\text { Persentase } \\
(\%)\end{array}$ \\
\hline Ya & 17 & 17 \\
Tidak & 83 & 83 \\
\hline \multicolumn{1}{c}{ Total } & 100,0 & 100,0 \\
\hline
\end{tabular}

Pada tabel 7 menunjukkan distribusi frekuensi faktor penyebab kejadian neonatus Risiko Tinggi berdasarkan kejadian preeklampsia, sebanyak $17 \%$ responden mengalami preeklampsia.

\section{Perdarahan postpartum}

Tabel 8.

Distribusi Frekuensi Faktor Perdarahan postpartum

\begin{tabular}{|c|c|c|}
\hline $\begin{array}{c}\text { Pendarahan saat } \\
\text { Kelahiran }\end{array}$ & Frekuensi & $\begin{array}{c}\text { Persentase } \\
(\%)\end{array}$ \\
\hline$\overline{Y a}$ & 8 & 8 \\
\hline Tidak & 92 & 92 \\
\hline Total & 100,0 & 100,0 \\
\hline
\end{tabular}

Pada tabel 8 menunjukkan distribusi frekuensi faktor penyebab kejadian neonatus Risiko Tinggi berdasarkan kejadian Perdarahan postpartum, sebanyak $8 \%$ responden mengalami kejadian Perdarahan postpartum.

\section{Indikasi Kejadian Neonatus Risiko Tinggi Berat Bayi Lahir}

Tabel 9.

Distribusi Frekuensi Berat Bayi Lahir

\begin{tabular}{lcc}
\hline Berat Bayi Lahir & Frekuensi & $\begin{array}{c}\text { Persentase } \\
(\%)\end{array}$ \\
\hline BBLR & 8 & 8 \\
Tidak BBLR & 92 & 92 \\
\hline \multicolumn{1}{c}{ Total } & 100,0 & 100,0 \\
\hline
\end{tabular}

Pada tabel 9 menunjukkan distribusi frekuensi indikasi kejadian neonatus Risiko Tinggi berdasarkan berat bayi yang dilahirkan responden, terlihat bahwa bayi yang mengalami BBLR (Berat Bayi Lahir Rendah) sebanyak 8\%.

\section{Kejadian Asfiksia}

Pada tabel 10 menunjukkan distribusi frekuensi indikasi kejadian neonatus Risiko Tinggi berdasarkan respon bayi saat dilahirkan yaitu kejadian asfiksia, terlihat bahwa sebanyak 37\% ibu mengalami kejadian asfiksia.

Tabel 10.

Distribusi Frekuensi Kejadian Asfiksia

\begin{tabular}{lcc}
\hline $\begin{array}{c}\text { Kejadian } \\
\text { Asfiksia }\end{array}$ & Frekuensi & $\begin{array}{c}\text { Persentase } \\
(\%)\end{array}$ \\
\hline Ya & 37 & 37 \\
Tidak & 63 & 63 \\
\hline \multicolumn{1}{c}{ Total } & 100,0 & 100,0 \\
\hline
\end{tabular}

Bayi Hipotermia

Tabel 11.

Distribusi Frekuensi Bayi Hipotermia

\begin{tabular}{lcc}
\hline Bayi Hipotermia & Frekuensi & $\begin{array}{c}\text { Persentase } \\
(\%)\end{array}$ \\
\hline Ya & 7 & 7 \\
Tidak & 93 & 93 \\
\hline \multicolumn{1}{c}{ Total } & 100,0 & 100,0 \\
\hline
\end{tabular}

Pada tabel 11 menunjukkan distribusi frekuensi indikasi kejadian neonatus Risiko Tinggi berdasarkan bayi hipotermia, terlihat bahwa terdapat $7 \%$ bayi yang dilahirkan mengalami hipotermia. Suhu normal bayi adalah antara 36,5$37,5^{\circ} \mathrm{C}$.

\section{Kejang Pada Bayi Baru Lahir}

Tabel 12.

Distribusi Frekuensi Kejang Pada Bayi Baru Lahir

\begin{tabular}{|c|c|c|}
\hline $\begin{array}{l}\text { Kejang pada Bayi } \\
\text { Baru Lahir }\end{array}$ & Frekuensi & $\begin{array}{c}\text { Persentase } \\
(\%)\end{array}$ \\
\hline $\mathrm{Ya}$ & 6 & 6 \\
\hline Tidak & 94 & 94 \\
\hline Total & 100,0 & 100,0 \\
\hline
\end{tabular}

Pada tabel 12 menunjukkan distribusi frekuensi indikasi kejadian neonatus Risiko Tinggi berdasarkan kejang pada bayi baru lahir, terlihat bahwa terdapat $6 \%$ bayi yang dilahirkan mengalami kejang.

Tahap 2 : Peningkatan Pemahaman mengenai Neonatus Risiko Tinggi

Pada penelitian tahap kedua dilakukan pendidikan kesehatan dengan pendekatan partisipatif kepada 27 responden. willcoxon test dilakukan, sebab data tidak berdistribusi normal, 
yaitu diperoleh nilai signifikansi 0,032 ( $p$ value < $0,05)$. Analisis hasil uji beda berdasarkan hasil pretest dan posttest dengan menggunakan willcoxon test disajikan dalam tabel sebagai berikut

Tabel 13.

Hasil Peningkatan Pemahaman mengenai Neonatus Risiko Tinggi

\begin{tabular}{lcc}
\hline $\begin{array}{c}\text { Pemahaman } \\
\text { mengenai Neonatus } \\
\text { Risiko Tinggi }\end{array}$ & Mean & p-value \\
\hline Pretest & 25,8 & 0,011 \\
Posttest & 27,4 & \\
\hline
\end{tabular}

Berdasarkan hasil pre-test dan post-test yang dilakukan untuk mengetahui tingkat pengetahuan ibu mengenai neonatal risiko tinggi, diperoleh hasil bahwa telah terjadi peningkatan kemampuan ibu setelah pendidikan kesehatan. Nilai rata-rata pengetahuan ibu mengalami kenaikan dari 25,8 saat pre-test dilakukan menjadi 27,4 saat posttest. Berdasarkan tabel 13 terlihat hasil penelitian dengan menggunakan willcoxon test, diperoleh $p$ value $0,011 \quad(<0,05)$ yang berarti bahwa terdapat perbedaan pemahaman antara pretest dan posttest, telah terjadi peningkatan nilai rata-rata pengetahuan responden mengenai neonatal risiko tinggi setelah dilakukan pendidikan kesehatan.

\section{PEMBAHASAN}

\section{Karakteristik Responden}

Distribusi frekuensi karakteristik responden dapat dilihat pada tabel 2, berdasarkan jenis pekerjaan, terlihat bahwa sebagian besar responden adalah IRT (Ibu Rumah Tangga) sebesar $79 \%$. Jenis pekerjaan perempuan dan suami medukung dalam pemanfaatan pelayanan kesehatan, namun, pada penelitian yang dilakukan di Indonesia membuktikan bahwa status perempuan yang bekerja dan pekerjaan suami tidak mempunyai dampak signifikan untuk mendapatkan pemeriksaan kehamilan dan pertolongan persalinan pada fasilitas pelayanan kesehatan (Kristiana, 2009). Berdasarkan tingkat pendidikan, sebagian besar responden berpendidikan SMA sebesar $50 \%$. Pendidikan yang ditempuh oleh seseorang merupakan salah satu faktor demografi yang sangat berpengaruh terhadap kondisi kesehatan individu maupun masyarakat. Seseorang dengan pendidikan yang tinggi, akan mudah menerima informasi-informasi kesehatan dari berbagai media dan biasanya ingin selalu berusaha untuk mencari informasi tentang hal-hal yang berhubungan dengan kesehatan yang belum diketahuinya.
Informasi kesehatan yang cukup terutama pada ibuibu hamil, terutama masalah kehamilan dan persalinan diharapkan akan dapat merubah perilaku hidup sehat termasuk dalam perilaku pemeriksaan kehamilan atau Antenatal Care (Kusumawati, 2006).

\section{Faktor Penyebab Kejadian Neonatus Risiko Tinggi Paritas Responden}

Paritas menunjukkan jumlah anak yang pernah dilahirkan oleh seorang wanita. Pada tabel 4 menunjukkan distribusi frekuensi faktor penyebab kejadian neonatus Risiko Tinggi berdasarkan paritas, terlihat bahwa hampir setengah responden memiliki paritas yang berisiko (49\%). Paritas merupakan faktor penting dalam menentukan nasib ibu dan janin baik selama kehamilan maupun selama persalinan. Pada ibu yang primipara (melahirkan bayi hidup) pertama kali, karena pengalaman melahirkan belum pernah, maka kemungkinan terjadinya kelainan dan komplikasi cukup besar baik pada kekuatan his (power), jalan lahir (passage), dan kondisi janin (pasagger). Informasi yang kurang tentang persalinan dapat pula mempengaruhi proses persalinan (Kusumawati, 2006).

Penelitian menunjukkan bahwa paritas merupakan faktor resiko, dimana besar resikonya adalah 2,4 yang artinya paritas beresiko (1 atau >3)mempunyai resiko 2,4 kali lebih besar untuk mengalami perdarahan postpar-tum dibandingkan paritas tidak bere-siko (2-3). Setiap kehamilan rahim mengalami pembesaran, terjadi peregangan otototot rahim. Akibat regangan tersebut elastisitas otot-otot rahim rahim tidak kembali seperti sebelum hamil setelah persalinan. Semakin sering ibu hamil dan melahirkan, semakin dekat jarak kehamilan dan kelahiran, elastisitas uterus semakin terganggu, akibatnya uterus tidak berkontraksi secara sempurna dan mengakibatkan perdarahan postpartum.( Saifudin. 2010) Hasil penelitian ini sejalan dengan penelitian Purwanti, S. (2014) menyimpulkan bahwa paritas juga berhubungan secara bermakna dengan kejadian perdarahan postpartum. Ibu hamil dengan paritas 1 atau lebih dari 3 memiliki risiko perdarahan postpartum 2,2 kali lebih besar dibandingkan ibu hamil yang dengan paritas 2 sampai 3 .

\section{Usia Responden}

Umur ibu saat hamil Usia ibu yang berisiko untuk terjadinya kematian maternal adalah usia kurang dari 20 tahun atau lebih dari 35 tahun.lbu yang hamil pada usia $<20$ tahun atau $>35$ tahun 
memiliki risiko untuk mengalami kematian maternal 3,4 kali lebih besar daripada ibu yang berusia 20 35 tahun (Fibriana,2007). Pada tabel 5 menunjukkan distribusi frekuensi faktor penyebab kejadian neonatus Risiko Tinggi berdasarkan usia responden, sebanyak $18 \%$ responden memiliki usia berisiko ( $<20$ tahun dan $>35$ tahun). Penelitian ini menunjukkan bahwa umur beresiko $(<20$ tahun atau $>35$ tahun) memiliki risiko mengalami perdarahan postpartum 3,7 kali lebih besar dibandingkan ibu yang berumur tidak beresiko ( 20 sampai 35 tahun).

Umur paling aman bagi seorang wanita untuk hamil dan melahirkan adalah umur antara 20 - 35 tahun, karena mereka berada dalam masa reproduksi sehat. komplikasi baik medis maupun obstetrik yang dapat membahayakan jiwa ibu, Kematian maternal pada ibu yang hamil dan melahirkan pada umur 35 tahun akan meningkatkan secara bermakna, karena mereka terpapar pada sehingga mengapa umur berpengaruh sebagai penyebab perdarahan postpartum. (Lestari, 2017). Usia kurang dari 20 th alat reproduksi tidak sehat sehingga sering timbul komplikasi persalinan. Umur lebih dari 35 tahun berhubungan dengan mulainya terjadi regenerasi sel - sel tubuh terutama dalam hal ini endometrium, akibat usia biologi jaringan dan adanya penyulit pada ibu hamil pada usia 36 tahun (Ummah, 2018). Pada usia < 20 tahun merupakan resiko tinggi kehamilan yang mengancam keselamatan ibu dan bayi hal ini disebabkan pada usia muda organorgan reproduksi dan fungsi fisiologisnya belum optimal secara psikologis belum tercapainya emosi dan kejiwaan yang cukup dewasa sehingga akan berpengaruh terhadap penerimaan kehamilannya yang akhirnya akan berdampak pada proses kehamilan persalinan hingga masa nifas.

Hasil penelitian ini sesuai dengan penelitian Ernawati (2018) menyimpulkan bahwa ibu dengan usia < 20 tahun masih berada dalam tahap pertumbuhan dan perkembangan sehingga kondisi hamil akan membuat dirinya harus berbagi dengan janin yang sedang di kandung untuk memenuhi kebutuhan gizinya, rahim dan panggul sering kali belum tumbuh mencapai ukuran dewasa. Sebagai akibatnya pada umur tersebut bila melahirkan bisa mengalami persalinan lama, sehingga beresiko terjadinya perdarahan postpartum. Bila umur diatas 35 tahun kondisi kesehatan sudah menurun sehingga hamil pada umur tersebut mempunyai kemung kinan lebih besar untuk terjadi persalinan lama dan perdarahan postpartum.

\section{Kejadian Anemia}

Keadaan anemia pada waktu hamil dapat meningkatkan frekuensi komplikasi saat kehamilan maupun persalinan, risiko kematian maternal, angka prematuritas, berat badan bayi lahir rendah, dan angka kematian perinatal meningkat. Perdarahan antepartum dan postpartum lebih sering dijumpai pada wanita yang anemia dan lebih sering berakibat fatal (Sulastri, 2015).

Pada tabel 6 menunjukkan distribusi frekuensi faktor penyebab kejadian neonatus Risiko Tinggi berdasarkan faktor kejadian anemia, sebanyak $20 \%$ responden mengalami kejadian anemia saat kehamilan. Ibu hamil yang anemia karena Hbnya rendah bukan hanya membahayakan jiwa ibu tetapi juga mengganggu pertumbuhan dan perkembangan serta membahayakan jiwa janin. Hal ini disebabkan karena kurangnya suplai nutrisi dan oksigen pada placenta yang akan berpengaruh pada fungsi placenta terhadap janin. Menurut Depkes RI (2008), batasan anemia adalah: Laki-laki Dewasa $>13$ gram \%, Wanita Dewasa $>12$ gram \%, Anak-anak $>11$ gram \%, Ibu Hamil > 11 gram \%. Jika kehamilan terjadi pada seorang ibu yang telah menderita anemia, maka perdarahan pasca persalinan dapat memperberat keadaan anemia dan berakibat fatal (Susilowati \& Fauzi, 2019) (Subiyanti, \& Afriana, 2016). Penelitian menunjukkan bahwaanemia merupakan faktor resiko, dimana besar resikonya adalah 1,8 , yang artinya ibu yang anemia $(\mathrm{Hb}<11)$ mempunyai risiko 1,8 lebih besar untuk mengalami perdarahan postpartum dibandingkan ibu yang tidak anemia $(\mathrm{Hb}$ >11). Kekurangan hemoglobin dalam darah dapat menyebabkan komplikasi lebih serius bagi ibu baik dalam kehamilan, persalinan dan nifas. Oksigen yang kurang pada uterus akan menyebabkan otototot uterus tidak berkontraksi dengan adekuat sehingga dapat timbul atonia uteri yang mengakibatkan perdarahan postpartum (Lestari, 2017). Anemia dapat mengurangi daya tahan tubuh ibu dan meninggikan frekuensi komlipkasi kehamilan serta persalinan. Anemia juga menyebabkan risiko perdarahan pasca persalinan. Penelitian ini sesuai dengan Amini dkk (2018) dan Aswar, dkk (2019) yang menyatakan bahwa anemia bermakna sebagai faktor risiko yang mempengaruhi perdarahan postpartum. Ibu yang mengalami anemia berisiko 2, kali mengalami perdarahan postpartum dibanding ibu yang tidak mengalami anemia .

\section{Preeklampsia}

Pada tabel 7 menunjukkan distribusi frekuensi faktor penyebab kejadian neonatus Risiko 


\section{Holidah, Fenita Purnama Sari Indah}

Tinggi berdasarkan kejadian preeklampsia, sebanyak $17 \%$ responden mengalami preeclampsia. Selain pada ibu, preeklampsia juga bisa berdampak pada bayi dalam kandungan. Besar dampak yang bisa dialami oleh bayi dalam kandungan tergantung dari usia kehamilan saat ibu mengalami preeklampsia dan seberapa parah tingkat tekanan darah tinggi ibu. Namun, dampak utama preeklampsia yang bisa diterima bayi adalah bayi kekurangan nutrisi karena tidak memadainya aliran darah rahim-plasenta. Hal ini bisa menyebabkan keterlambatan pertumbuhan bayi dalam kandungan, kelahiran prematur, atau bayi lahir mati (stillbirth).

Terganggunya aliran darah menuju plasenta dapat menyebabkan bayi kekurangan nutrisi sehingga mengganggu pertumbuhan bayi dalam kandungan. Penelitian jangka panjang telah membuktikan bahwa keterlambatan pertumbuhan janin dalam rahim atau intrauterine growth retardation (IUGR) dapat menyebabkan hipertensi, penyakit jantung koroner, dan diabetes saat bayi sudah besar nanti.

Adriana melaporkan hasil yang berbeda, bahwa berat badan lahir rendah akan menimbulkan komplikasi medis yang lebih berpengaruh terhadap morbiditas dan mortalitas janin yang dilahirkan, hal ini disebabkan oleh kekurangan surfaktan, pertumbuhan dan pengembangan paru yang belum sempurna, otot pernapasan yang masih lemah dan tulang iga yang mudah melengkung, perdarahan intraventikuler. Oleh karena itulah bayi dengan BBLR atau prematur sering menderita apneu, asfiksia berat dan sindroma gangguan pernapasan. Bayi berat lahir rendah lebih merupakan masalah penting dalam pengelolaannya karena mempunyai kecenderungan ke arah peni Preeklampsia adalah kelainan malfungsi endotel pembuluh darah atau vaskular yang menyebar luas sehingga terjadi vasospasme setelah usia kehamilan 20 minggu, mengakibatkan terjadinya penurunan perfusi organ dan pengaktifan endotel yang menimbulkan terjadinya hipertensi, edema, dan dijumpai proteinuria $300 \mathrm{mg}$ per $24 \mathrm{jam}$ atau $30 \mathrm{mg} / \mathrm{dl}(+1$ pada dipstick) pada minimal dua sampel urin secara acak yang dikumpulkan setidaknya 4-6 jam tetapi tidak lebih dari 7 hari. Hilangnya semua kelainan tersebut sebelum akhir minggu keenam postpartum (Sibai, 2005; Brooks, 2011). Terlepas dari keparahan preeklampsia, tidak ada keuntungan dalam melanjutkan kehamilan ketika preeklampsia ditemukan setelah usia kehamilan 36-37 minggu. Pada usia kehamilan $34 \quad-37$ minggu, penatalaksanaan tergantung pada tingkat keparahan preeklampsia. Penanganan memungkinkan untuk dilakukan terhadap preeklampsia ringan untuk membatasi risiko induksi persalinan prematur, tetapi untuk preeklampsia berat, persalinan meningkatkan risiko pada ibu dan komplikasi janin (Haddad, 2009).

\section{Perdarahan postpartum}

Pada tabel 8 menunjukkan distribusi frekuensi faktor penyebab kejadian neonatus Risiko Tinggi berdasarkan kejadian Perdarahan postpartum, sebanyak $8 \%$ responden mengalami kejadian Perdarahan postpartum. Perdarahan postpartum (PPP) didefinisikan sebagai kehilangan $500 \mathrm{ml}$ atau lebih darah setelah persalinan pervaginam atau $1000 \mathrm{ml}$ atau lebih setelah seksio sesaria (Leveno, 2009; WHO, 2012). Faktor risiko Perdarahan postpartum dapat ada saat sebelum kehamilan, saat kehamilan, dan saat persalinan. Faktor risiko sebelum kehamilan meliputi usia, indeks massa tubuh, dan riwayat perdarahan postpartum. Faktor risiko selama kehamilan meliputi usia, indeks massa tubuh, riwayat perdarahan postpartum, kehamilan ganda, plasenta previa, preeklampsia, dan penggunaan antibiotik. Sedangkan untuk faktor risiko saat persalinan meliputi plasenta previa anterior, plasenta previa mayor, peningkatan suhu tubuh $>37^{\circ}$, korioamnionitis, dan retensio plasenta (Briley et al., 2014).

Perdarahan postpartum juga berhubungan dengan obesitas. Risiko perdarahan akan meningkat dengan meningkatnya indeks massa tubuh. Pada wanita dengan indeks massa tubuh lebih dari 40 memiliki resiko sebesar 5,2\% dengan persalinan normal (Blomberg, 2011).

\section{Indikasi Kejadian Neonatus Risiko Tinggi Berat Bayi Lahir}

Pada tabel 9 menunjukkan distribusi frekuensi indikasi kejadian neonatus Risiko Tinggi berdasarkan berat bayi yang dilahirkan responden, terlihat bahwa bayi yang mengalami BBLR (Berat Bayi Lahir Rendah) sebanyak 8\%. Adriana melaporkan hasil yang berbeda, bahwa berat badan lahir rendah akan menimbulkan komplikasi medis yang lebih berpengaruh terhadap morbiditas dan mortalitas janin yang dilahirkan, hal ini disebabkan oleh kekurangan surfaktan, pertumbuhan dan pengembangan paru yang belum sempurna, otot pernapasan yang masih lemah dan tulang iga yang mudah melengkung, perdarahan intraventikuler. Oleh karena itulah bayi dengan BBLR atau prematur sering menderita apneu, asfiksia berat dan sindroma gangguan pernapasan. (Pratama, dkk, 2018 dan Adriana, dkk, 2015). 


\section{Kejadian Asfiksia}

Pada tabel 10 menunjukkan distribusi frekuensi indikasi kejadian neonatus Risiko Tinggi berdasarkan respon bayi saat dilahirkan yaitu kejadian asfiksia, terlihat bahwa sebanyak $37 \%$ ibu mengalami kejadian asfiksia. Asfiksia pada bayi baru lahir atau asfiksia neonatorum adalah suatu keadaaan bayi baru lahir yang gagal bernafas secara spontan dan teratur segera setelah lahir. Asfiksia dapat mengakibatkan kematian dan diperkirakan satu juta anak yang bertahan setelah mengalami asfiksia saat lahir kini hidup dengan morbiditas jangka panjang seperti cerebral palsy, retardasi mental, dan gangguan belajar faktor-faktor risiko terjadinya asfiksia neonatorum adalah faktor ibu, faktor plasenta, faktor janin, dan faktor persalinan. kejadian asfiksia bisa disebabkan oleh fungsi plasenta yang tidak maksimal lagi akibat proses penuaan. Proses penuaan atau penurunan fungsi ini mengakibatkan transportasi oksigen dan pasokan makanan dari ibu ke janin juga menurun atau terganggu. Persalinan adalah rangkaian peristiwa mulai dari membuka dan menipisnya serviks sampai dikeluarkannya produk konsepsi dari uterus ke dunia luar. Persalinan yang normal pada multipara maksimum berlangsung selama 16-18 jam dan pada primipara maksimum berlangsung selama 24 jam (Rahma dan Armah, 2014).

Asfiksia adalah kegagalan bernapas secara spontan dan teratur pada saat lahir atau beberapa saat setelah lahir yang ditandai dengan keadaan $\mathrm{PaO}_{2}$ di dalam darah rendah (hipoksemia), hiperkarbia $\left(\mathrm{Pa} \mathrm{CO} \mathrm{CO}_{2}\right.$ meningkat) dan asidosis. Penyebab asfiksia dapat berasal dari faktor ibu, janin dan plasenta. Adanya hipoksia dan iskemia jaringan menyebabkan perubahan fungsional dan biokimia pada janin. Faktor ini yang berperan pada kejadian asfiksia.

\section{Bayi Hipotermia}

Pada tabel 11 menunjukkan distribusi frekuensi indikasi kejadian neonatus Risiko Tinggi berdasarkan bayi hipotermia, terlihat bahwa terdapat $7 \%$ bayi yang dilahirkan mengalami hipotermia. Suhu normal bayi adalah antara 36,5$37,5^{\circ} \mathrm{C}$. Hipotermia dibagi menjadi tiga jenis yaitu stres dingin, hipotermia sedang, dan hipotermia berat. Batasan stres dingin suhu antara 35,5$36,4^{\circ} \mathrm{C}$, hipotermia sedang suhu antara $32-35,4^{\circ} \mathrm{C}$, dan hipotermia berat apabila suhu kurang dari $32^{\circ} \mathrm{C}$. Bila tubuh dan ekstremitas hangat maka interpretasinya adalah normal. Bila tubuh teraba hangat tapi ekstremitas teraba dingin maka berarti bayi mengalami stres dingin. Sedangkan bila tubuh dan ekstremitas teraba dingin berarti bayi mengalami hipotermia. Pada perabaan tidak dapat ditentukan gradasi hipotermia. Masalah pada suhu bayi baru lahir adalah hipotermia atau suhu tubuh kurang dari $36,5^{\circ} \mathrm{C}$ dan demam. Banyak penyakit memiliki gejala hipotermia di antaranya infeksi berat seperti sepsis neonatorum, radang selaput otak, radang paru, hipoglikemi, dan lain-lain. Hipotermia merupakan hal berbahaya yang perlu penanganan segera.

\section{Kejang Pada Bayi Baru Lahir}

Pada tabel 12 menunjukkan distribusi frekuensi indikasi kejadian neonatus Risiko Tinggi berdasarkan kejang pada bayi baru lahir, terlihat bahwa terdapat $6 \%$ bayi yang dilahirkan mengalami kejang. Untuk mengetahui penyebab kejang pada bayi baru lahir, perlu dilakukan pemeriksaan menyeluruh, baik dengan tanya jawab lebih rinci mengenai kehamilan dan persalinan, pemeriksaan fisik pada bayi serta pemeriksaan penunjang. Laboratorium saja tidak bisa digunakan untuk menentukan diagnosis.

Kejang pada bayi baru lahir bisa disebabkan oleh Kekurangan oksigen pada saat kelahiran, misalnya disebabkan oleh persalinan lama, lilitan tali pusat, solusio plasenta, dan lain sebagainya, infeksi pada sebelum atau setelah kelahiran, kekurangan gula darah (hipoglikemia), gangguan elektrolit seperti hiponatremia (kekurangan natrium), hipokalsemia (kekurangan kalsium), hipernatremia (kelebihan natrium) dan lain sebagainya, stroke, kelainan metabolic, gejala putus obat, terutama pada ibu yang menggunakan obat terlarang saat kehamilan, kelainan bawaan lainnya.

\section{Tahap 2 : Peningkatan Pemahaman mengenai Neonatus Risiko Tinggi}

Berdasarkan tabel 13 terlihat hasil penelitian dengan menggunakan willcoxon test, diperoleh $p$ value $0,011 \quad(<0,05)$ yang berarti bahwa terdapat perbedaan pemahaman antara pretest dan posttest, telah terjadi peningkatan nilai rata-rata pengetahuan responden mengenai neonatal risiko tinggi setelah dilakukan pendidikan kesehatan. Berdasarkan hasil pre-test dan post-test yang dilakukan untuk mengetahui tingkat pengetahuan ibu mengenai neonatal risiko tinggi, diperoleh hasil bahwa telah terjadi peningkatan kemampuan ibu setelah pendidikan kesehatan. Nilai rata-rata pengetahuan ibu mengalami kenaikan dari 25,8 saat pre-test dilakukan menjadi 27,4 saat post-test. Perubahan pada saat setelah dilakukan pendidikan kesehatan, masyarakat dapat memahami dengan baik dari materi yang diberikan. Pemahaman ibu saat 


\section{Holidah, Fenita Purnama Sari Indah}

dilakukan pendekatan partisipatif yaitu dengan melakukan pendidikan kesehatan mengenai ciri dan penyebab neonatus berisiko tinggi, faktor yang mempengaruhi terjadinya neonatus berisiko tinggi serta upaya yang harus dilakukan terhadap bayi neonatus risiko tinggi.

Penelitian terkait masih terbatas pada peningkatan pemahaman ibu bayi dan balita mengenai asi eksklusif maupun gizi ibu. Belum terdapat penelitian mengenai peningkatan pemahaman ibu mengenai neonatus risiko tinggi. Pada penelitian yang berkaitan dengan gizi buruk pada balita, penelitian ini sesuai dengan penelitian yang telah dilakukan oleh Soesanto dan Mustaqin yang mengatakan bahwa ada perbedaan secara bermakna tingkat pengetahuan responden tentang gizi buruk sebelum dan setelah dilakukan pendidikan kesehatan dengan uji statistik independent sample $t$ test diperoleh nilai $p$ sebesar 0.000 (< 0.05). Hasil ini juga sejalan dengan penelitian yang dilakukan oleh Widyaningtyas yang mengatakan bahwa terdapat perbedaan yang signifikan antara pengetahuan ibu tentang MP ASI kepada balita usia 6-24 bulan sebelum dan sesudah mendapatkan penyuluhan dengan $p$ value sebesar (0.047) dimana nilai $p$ value $<0,05$.

\section{SIMPULAN}

Berdasarkan hasil penelitian diperoleh hasil faktor penyebab kejadian neonatus risiko tinggi yang terdapat pada 100 ibu yang memiliki bayi dan balita, hampir setengah responden memiliki paritas yang berisiko $(49 \%)$, sebanyak $18 \%$ responden memiliki usia berisiko ( $<20$ tahun dan $>35$ tahun), sebanyak 20\% responden mengalami kejadian anemia saat kehamilan, sebanyak $17 \%$ responden mengalami preeclampsia dan sebanyak $8 \%$ responden mengalami kejadian Perdarahan postpartum. Jika dilihat dari indikasi kejadian neonatus risiko tinggi, maka dihasilkan bahwa bayi yang mengalami BBLR (Berat Bayi Lahir Rendah) sebanyak $8 \%$, sebanyak $37 \%$ ibu mengalami kejadian asfiksia, $7 \%$ bayi yang dilahirkan mengalami hipotermia, dan $6 \%$ bayi yang dilahirkan mengalami kejang. Pada penelitian ini diperoleh hasil bahwa terdapat perbedaan pemahaman antara pretest dan posttest, telah terjadi peningkatan nilai rata-rata pengetahuan responden mengenai neonatal risiko tinggi setelah dilakukan pendidikan kesehatan. Nilai rata-rata pengetahuan ibu mengalami kenaikan dari 25,8 saat pre-test dilakukan menjadi 27,4 saat post-test.

\section{SARAN}

Bagi bagi instansi kesehatan dapat meningkatkan pemahaman ibu hamil serta ibu yang memiliki bayi dan balita dengan cara yang lebih inovatif dan partisipatif tentang faktor penyebab kejadian neonatus risiko tinggi maupun indikasi kejadian neonatus risiko tinggi pada ibu. Bagi Masyarakat dapat meningkatkan pengetahuan dan wawasan sebagai acuan agar dapat mencegah terjadinya kejadian neonatus risiko tinggi pada ibu hamil serta ibu yang memiliki bayi dan balita.

\section{DAFTAR PUSTAKA}

Alim, A., Adam, A., \& Dimi, B. (2020). Prevalensi Malaria Berdasarkan Karakteristik Sosio Demografi. Jurnal IImiah Kesehatan, 19(01), 4-9.

Amini, A., Pamungkas, C. E., \& Harahap, A. P. H. P. (2018). Usia Ibu dan Paritas sebagai Faktor Risiko yang Mempengaruhi Kejadian Anemia pada Ibu Hamil di Wilayah Kerja Puskesmas Ampenan. Midwifery Journal: Jurnal Kebidanan UM. Mataram, 3(2), 108113.

Arliman, L. (2018). Eksistensi Hukum Lingkungan dalam Membangun Lingkungan Sehat Di Indonesia. Lex Librum: Jurnal IImu Hukum, 5(1), 761-770.

Aswar, S., Pamungkas, S. E., \& Ulfiani, N. (2019). Determinan Kejadian Pendarahan Postpartum Di Rsud Kabupaten Biak Numfor. Jurnal Keperawatan Tropis Papua, 2(1), 73-79.

Dwiargatra, A., \& Purhadi, P. (2020). Pemodelan Faktor-Faktor yang Mempengaruhi Angka Kematian Bayi dan Angka Kematian Anak di Provinsi Jawa Timur Tahun 2017 Menggunakan Bivariat Gamma Regression. Jurnal Sains dan Seni ITS, 8(2), D97-D104.

Ernawati, A. (2018). Hubungan Usia Dan Status Pekerjaan Ibu Dengan Kejadian Kurang Energi Kronis Pada Ibu Hamil. Jurnal Litbang: Media Informasi Penelitian, Pengembangan dan IPTEK, 14(1), 27-37.

Hidayat AA. (2011) Metode penelitian kebidanan dan teknik analisis data. Jakarta: Salemba Medika

Hidayat, R. A. (2017). Hak Atas derajat pelayanan kesehatan yang optimal. Syariah: Jurnal Hukum dan Pemikiran, 16(2), 127-134.

Kementrian Kesehatan RI. (2014). Medika Pusat data dan informasi profil kesehatan Indonesia 2014. Jakarta: Kementrian Kesehatan RI 
JKM (Jurnal Kebidanan Malahayati),Vol 7,No.3.Juli 2021,

ISSN (Print) 2476-8944 ISSN (Online) 2579-762X, Hal 533-543

Khasanah, N. (2013). Dampak Persepsi Budaya terhadap Kesehatan Reproduksi lbu dan Anak di Indonesia. MUWAZAH: Jurnal Kajian Gender, 3(2).

Lestari, G. I. (2017). Analisis Hubungan Anemia Dengan Perdarahan Postpartum Di Rsud Jendral Ahmad Yani Kota Metro Tahun 2013. Jurnal Kesehatan Metro Sai Wawai, 7(2), 65-76.

Liufeto, A. M., \& Angi, Y. F. (2019). Anggaran Responsif Gender Pada APBD Provinsi Nusa Tenggara Timur Tahun 20172019. Jurnal Akuntansi: Transparansi dan Akuntabilitas, 7(2), 99-110.

Maghfiroh, L. (2015) Pertambahan Berat Badan Ibu Hamil dan Kejadian Berat Bayi Lahir Rendah (BBLR) di Wilayah Kerja Puskesmas Pamulang Tahun 2013-2015.

Nurhafni, N., Yarmaliza, Y., \& Zakiyuddin, Z. (2021). Analisis Faktor Risiko Terhadap Angka Kematian Bayi Di Wilayah Kerja Puskesmas Johan Pahlwan (Rundeng) Kabupaten Aceh Barat. Jurmakemas (Jurnal Mahasiswa Kesehatan Masyarakat), 1(1), 9-20.

Palimbo A, RR., SriRedjeki, D.S., Kartikasari, A. (2015). Gambaran Faktor Penyebab Terjadinya Asfiksia Neonaturum Pada Bayi Baru Lahir Di Ruang Perinatalogi Rsu Dr. H. Moch. Ansari Saleh Banjarmasin. Banjarmasin: Dinamika Kesehatan.

Perwira, I. (2014). Memahami kesehatan sebagai hak asasi manusia. Jurnal ELSAM, Jakarta.

Pinontoan, V. M., \& Tombokan, S. G. (2015). Hubungan umur dan paritas ibu dengan kejadian bayi berat lahir rendah. JIDAN (Jurnal IImiah Bidan), 3(1), 20-25.

Prahutama, A., Sudarno, S., Suparti, S., \& Mukid, M. A. (2017). Analisis Faktor-Faktor yang Mempengaruhi Angka Kematian Bayi di Jawa Tengah Menggunakan Regresi Generalized Poisson dan Binomial Negatif. Jurnal Statistika Universitas Muhammadiyah Semarang, 5(2).

Pratama, dkk, Pratama, A.S., Hanum L., Handoyo, Y.B. (2018). Angka Kejadian Asfiksia Neonatorum Pada Bayi Dengan Berat Badan Lahir Rendah Di Rsud Goeteng Taroenadibrata Purbalingga. Herb-Medicine $\begin{array}{llll}\text { Journal, } & 1 & \text { (2), } & \text { 92-97. }\end{array}$ http://dx.doi.org.10.30595/hmj.v1i2.3098

Purwanti, S (2014). Determinan Faktor Penyebab Kejadian Perdarahan Post Partum Karena
Atonia Uteri di RSUD Margono Soekarjo Tahun 2014

Rahma dan Armah. (2014). Analisis Faktor Risiko Kejadian Asfiksia Pada Bayi Baru Lahir Di RSUD Syekh Yusuf Gowa dan RSUP Dr Wahidin Sudirohusodo Makassar, Jurnal Kesehatan, 7 (1).

Rahmawati, E. B. S., Kuntoro, R., \& Trijanto, B. (2016). Keikutsertaan Kelas Ibu Hamil Berpengaruh terhadap Pengetahuan dan Sikap Ibu dalam Praktik Inisiasi Menyusu Dini. Majalah Obstetri dan Ginekologi, 24(1), 8-12.

Saputra, W., Fanggidae, V., \& Mafthuchan, A. (2013). Efektivitas kebijakan daerah dalam penurunan angka kematian ibu dan bayi. Kesmas: Jurnal Kesehatan Masyarakat Nasional (National Public Health Journal), 7(12), 531-537.

Sary, S. A., \& Latra, I. N. (2013). Pemodelan Jumlah Kematian Bayi di Provinsi Jawa Timur Tahun 2011 dengan Pendekatan Regresi Binomial Negatif. Jurnal Sains dan Seni ITS, 2(2), D282-D287.

Sulastri, Maliya A, Zulaicha E susilaningsih. (2014). Model Pencegahan Anemia Pada Ibu Hamil Untuk Menurunkan Perdarahan Post Partum. Prosiding Nasional dan Internasional Semarang, LPPM Universitas Muhammadiyah Semarang

Susilowati, L., \& Fauzi, L. N. (2019). Faktor-faktor yang berhubungan Dengan Kejadian Anemia Pada Ibu Hamil. Jurnal Antara Kebidanan, 2(1), 46-53.

Ummah, N., Ngadiyono, N., \& Ulfiana, E. (2018). Faktor resiko penyebab perdarahan postpartum di Puskesmas Pamotan Kabupaten Rembang. Jurnal Kebidanan, 7(15), 39-49.

Ummah, Nurul. (2018). Faktor risiko penyebab perdarahan post partum di Puskesmas Pamotan Kabupaten Rembang. Jurnal Kebidanan 7 (15)

UPT Puskesmas Pamulang. (2018). Profil Puskesmas Pamulang, Tangerang Selatan.

Wahyuni, R. (2020). Faktor Penyebab Terjadinya Ketuban Pecah Dini pada Ibu Bersalin di Rumah Sakit Umum Daerah Sumbawa Besar. Jurnal Kesehatan dan Sains, 3(2), 26-33. 